\title{
Wpływ budowy geologicznej i rzeźby na procesy kształtujące skład chemiczny wód w czasie wezbrania roztopowo- deszczowego w zlewni Bystrej w Tatrach Zachodnich
}

\author{
Effect of geology and relief on processes shaping water chemistry in the rain-on-snow event \\ in the Bystra catchment in the Western Tatras in Poland
}

\section{Monika Sajdak ๑*, Joanna P. Siwek ๑ , Mirosław Żelazny ๑ , Izabela Dojtrowska}

Instytut Geografii i Gospodarki Przestrzennej, Uniwersytet Jagielloński w Krakowie, ${ }^{*}$ monika.sajdak@doctoral.uj.edu.pl

\begin{abstract}
Zarys treści: Celem badań było rozpoznanie procesów kształtujących skład chemiczny wód potoków odwadniających krystaliczną i osadowa czesść zlewni Potoku Bystra w Tatrach w czasie wezbrania roztopowo-opadowego w kwietniu 2016 r. Badania były prowadzone $\mathrm{w}$ dwóch przekrojach wodowskazowych reprezentujących obszary zbudowane ze skał krystalicznych (Goryczkowy Potok), oraz ze skał osadowych, charakteryzujacych się rozbudowanymi systemami krasowymi (Potok Bystra). Głównym procesem kształtującym zmiany składu chemicznego wody w obu zlewniach w czasie analizowanego wezbrania był proces rozcieńczania wód podziemnych wodami roztopowymi i opadowymi. Przejawiało się to spadkiem stężenia większości jonów w potokach wraz ze wzrostem stanów wody. W Potoku Bystra, odwadniającym obszar osadowy zmiany składu chemicznego były dodatkowo modyfikowane dopływem wód z systemów krasowych a w Goryczkowym Potoku - wymywaniem jonów z gleby przez wody spływu śródpokrywowego.
\end{abstract}

Słowa kluczowe: zlewnie wysokogórskie, wezbrania roztopowo-deszczowe, chemizm wód, Tatry

Abstract: The purpose of the study was to identify processes shaping water chemistry in streams draining the crystalline and sedimentary portions of the Bystra Stream catchment in the Tatras during rain-on-snow event in April 2016. Data were gathered at two water gauging sites representative of areas formed of crystalline rock (i.e. Goryczkowy Stream) and areas formed of sedimentary rock characterized by extensive karst systems (Bystra Stream). The main process responsible for changes in water chemistry in both catchments over the study period was dilution of groundwater with snowmelt and precipitation water. This was manifested via a decrease in the concentration of most ions in the studied streams at high water stages. The water chemistry of Bystra Stream draining sedimentary rocks was affected in part also by the influx of water from karst systems. In the Goryczkowy Potok Stream the changes were modified by flushing of ions from the soil by throughflow.

Key words: high-mountain catchments, rain-on-snow event, water chemistry, the Tatras

\section{Wstęp}

Skład chemiczny wód rzecznych w czasie wezbrań odznacza się zazwyczaj dużą dynamiką. Ilość substancji rozpuszczonych $\mathrm{w}$ wodzie podlega ciągłym zmianom i jest zależna od natężenia przepływu (Froehlich 1982, Zwoliński 1989, Krzemień 1991, Kostrzewski i in. 1993, Kostrzewski i in. 1994, Mazurek 2000). Zależność ta bardzo często może mieć nieliniowy charakter (Froehlich 1982, Smolska 1996). W czasie wezbrań do koryta dopływają w stosunkowo krót- kim czasie wody będące na różnym etapie krążenia: wody opadowe bezpośrednio zasilające potok, wody spływu powierzchniowego, wody śródpokrywowe oraz wody podziemne. Wody te charakteryzują się różnymi właściwościami chemicznymi, a zmiana ich udziału w odpływie w czasie wezbrań powoduje dynamiczne zmiany składu chemicznego wód rzecznych (Kostrzewski i in. 1992). Sposób zasilania cieków w czasie wezbrań, a więc czas i wielkość dopływu do koryta poszczególnych składowych odpływu rzecznego, uzależniony jest głównie od czynników 
hydrometeorologicznych, takich jak intensywności opadów atmosferycznych (Cameron 1996, Siwek i in. 2017), zmiany przepływu rzecznego (Zwoliński 1989, Kostrzewski i in. 1992, Kendall i in. 1999, Abesser $i$ in. 2006) oraz stopnia uwilgotnienia i przemarznięcia pokryw glebowych (Walling, Foster 1975; Foster 1978, Caissie i in. 1996, Laudon i in. 2004, Siwek i in. 2013a, b, 2017 ). Ważnym czynnikiem kształtującym sposób zasilania cieków w czasie wezbrań są także cechy zlewni: jej budowa geologiczna (Walling, Webb 1980, Caissie i in. 1996, Holloway, Dahl- gren 2001), rzeźba terenu i wysokość nad poziomem morza (Edwards 1973, Kendall i in. 1999, McGlynn i in. 1999, Stottlemyer 2001) oraz przepuszczalność pokryw glebowo-zwietrzelinowych (Bazemore i in. 1994, Hinton i in. 1994, Mulder i in. 1995, Sandén i in. 1997, Siwek i in. 2017). Obecnie bardzo ważną rolę w kształtowaniu zarówno sposobu zasilania cieków jak i zmian składu chemicznego wód rzecznych w czasie wezbrań pełni gospodarcza działalność człowieka (Poor, McDonnell 2007, Siwek i in. 2013a, b, 2017). Wszystkie te uwarunkowania wzajemnie się

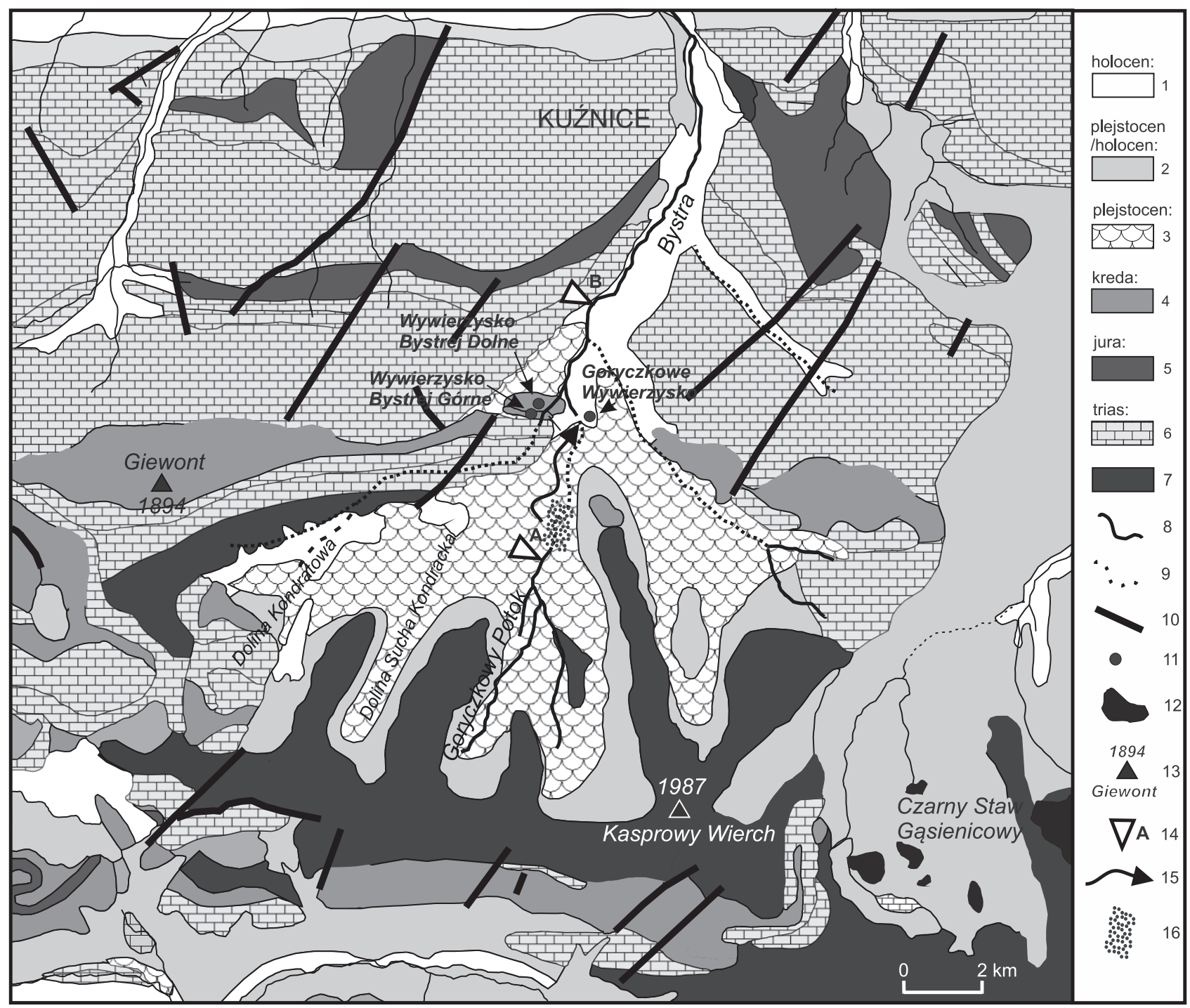

Ryc. 1. Budowa geologiczna obszaru badań (Piotrowska i in. 2015)

1 - piaszczysto-żwirowe gliny i piaski glniaste, 2 - głazy, rumosze skalne, żwiry, 3 - żwiry piaszczyste oraz piaski i głazy, 4 - łupki, margle, wapienie: piaszczyste, rafowe, rogowcowe, organogeniczne, masywne wapienie bulaste czerwone; piaskowce, 5 - wapienie margliste, piaskowce kwarcowe, 6 - wapienie, dolomity, łupki piaszczyste, piaskowce kwarcowe, zlepieńce, 7 - skały krystaliczne, 8 - cieki, 9 - cieki okresowe, 10 - uskoki, 11 - wywierzyska, 12 - jeziora, 13 - szczyty, 14 - punkty pomiarowe: A - Goryczkowy Potok, B - Potok Bystra, 15 - prawdopodobny przepływ wody w czasie wezbrania, 16 - strefa ponorowa

Fig. 1. Geologic structure of study area (Piotrowska et al. 2015)

1 - sandy to gravel loams, cleyey sands, 2 - blocks, rock-rubble, gravels, 3 - sandy gravels, sands, blocks, 4 - grey shales, marls, sandy limestones, light-coloured riff limestones, grey hornfels limestones, massive organogenic limestones, red nodular limestones, sandstones, 5 - marly limestones, quartzstones sandstones, 6 - limestones, dolomites, sandy shales, sandstones, quartzstones, conglomerates, 7 - crystalline rocks, 8 - stream, 9 - ephemeral stream, 10 - fault, 11 - karst Spring, 12 - lake, 13 - peak, 14 - gauging sites: A - Goryczkowy Stream, B - Bystra Stream, 15 - supposed water flow during snowmelt and rainfall event, 16 - sinkhole 
przenikają, co stwarza problemy w wyodrębnieniu czynników naturalnych od czynników antropogenicznych. Zlewnie tatrzańskie są jednak obszarami o niewielkiej ingerencji człowieka, stąd też są cenne dla prowadzenia obserwacji naturalnych procesów hydrochemicznych i geomorfologicznych. W obszarze tatrzańskim dotychczas nie prowadzono szczegółowych badań składu chemicznego wód w czasie wezbrań.

Prezentowane badania zmierzały do rozpoznania wpływu budowy geologicznej i rzeźby na procesy kształtujące zmiany składu chemicznego wód potoków odwadniających krystaliczną i osadową część zlewni Potoku Bystra w czasie wezbrania roztopowo-deszczowego, które wystąpiło w kwietniu 2016 r.

\section{Obszar badań}

Badania prowadzono w zlewni Potoku Bystra oraz w jednej z jej zlewni cząstkowych, zlewni Goryczkowego Potoku (ryc. 1). Zlewnia potoku Bystra znajduje się w polskiej części Tatr, na granicy Tatr Wysokich i Zachodnich (Kondracki 2002). Zajmuje ona $12,23 \mathrm{~km}^{2}$, natomiast jej średnie nachylenie wynosi $26,8^{\circ}$ (Żelazny 2012). Najwyższy szczyt Kondracka Kopa ma wysokość 2004 m n.p.m.

Budowa geologiczna zlewni Potoku Bystra jest szczególnie złożona. W jej południowej części znajduje się oderwana od paleozoicznego trzonu krystalicznego czapka tektoniczna usytuowana na skałach serii wierchowych (ryc. 1). Goryczkowy Potok odwadnia południową, krystaliczną część zlewni zbudowaną ze skał granitowych i metamorficznych. Ta część zlewni ulegała intensywnym przekształceniom w okresie plejstocenu, czego efektem są obecnie kotły lodowcowe oraz osady morenowe wyścielające dno doliny Goryczkowego Potoku i Potoku Kondrackiego (Klimaszewski 1988). Goryczkowy Potok po opuszczeniu części krystalicznej stopniowo zanika w utworach morenowo-piargowych Hali Goryczkowej, które są podścielone skałami osadowymi serii wierchowych, ze znacznym udziałem krasowiejących wapieni. W południowej części zlewni na utworach krystalicznych wykształciły się rankery, gleby inicjalne rumoszowe i bielice (Piotrowska i in. 2015, Skiba $\mathrm{i}$ in. 2015).

Północna część zlewni zbudowana jest głównie $z$ krasowiejących skał osadowych, wapieni i dolomitów, a także zlepieńców, piaskowców kwarcowych, łupków i margli (Piotrowska i in. 2015). Ta część zlewni odwadniana jest przez Potok Bystra. Potok ten zasilany jest przez trzy bardzo wydajne wywierzyska, dwa stałe: wywierzysko Bystrej Dolne i Goryczkowe Wywierzysko oraz okresowe wywierzysko Bystrej Górne, które zanika w okresie niskiego nawodnie-
Tabela 1. Skład chemiczny wód wywierzysk w 2016 r.

Table 1. Chemical composition of karst spring water in 2016

\begin{tabular}{crc}
\hline \multirow{2}{*}{ Cecha } & $\begin{array}{c}\text { Goryczkowe } \\
\text { Wywierzysko }\end{array}$ & $\begin{array}{c}\text { Wywierzyska } \\
\text { Bystrej }\end{array}$ \\
\cline { 2 - 3 } & \multicolumn{2}{c}{$\left[\mathrm{mg} \mathrm{dm}^{-3}\right]$} \\
\hline Mineralizacja & 78,8 & 83,4 \\
$\mathrm{Ca}^{2+}$ & 14,8 & 15,4 \\
$\mathrm{Mg}^{2+}$ & 2,9 & 3,1 \\
$\mathrm{Na}^{+}$ & 0,9 & 0,9 \\
$\mathrm{~K}^{+}$ & 0,4 & 0,34 \\
$\mathrm{HCO}_{3}^{-}$ & 49,9 & 54,8 \\
$\mathrm{SO}_{4}{ }^{2-}$ & 7,8 & 6,7 \\
$\mathrm{Cl}^{-}$ & 0,3 & 0,3 \\
$\mathrm{NO}_{3}^{-}$ & 1,8 & 1,7 \\
\hline
\end{tabular}

nia masywu, zwykle w zimie. Wywierzyska Bystrej położone są na wschodnich stokach Kalackiej Turni na wysokości 1165-1170 m n.p.m., a Goryczkowe Wywierzysko jest położone na północno-zachodnich stokach Myślenickich Turni na wysokości 1190 m n.p.m. (Wit, Ziemońska 1960, Barczyk 2008). Wywierzysko Goryczkowe wypływa z rozległej misy erozyjnej wyżłobionej w dnie potoku (Małecka 1997). System zasilający wywierzyska Bystrej Górne i Dolne rozwinął się $\mathrm{w}$ utworach węglanowych triasu środkowego i malmo-nekomu. Wywierzyska są zlokalizowane na zboczach Kalackiej Turni w odległości około 15 m (Małecka 1997). Dyskusyjny pozostaje obszar alimentacji źródeł. Według Małeckiej (1993, 1997) głównym obszarem ich alimentacji jest masyw Giewontu. Badania hydrologiczno-chemiczne przeprowadzone przez Gromadzką i in. (2015) wykazały, że bardziej prawdopodobnym obszarem ich zasilania są doliny odwadniające krystaliczną część zlewni Potoku Bystra (np. Dolina Kondratowa, Dolina Sucha Kondracka). Obszar alimentacji Goryczowego Wywierzyska został zidentyfikowany metodą barwienia przez Dąbrowskiego i Głazka (1968) i znajduje się w górnej części zlewni Suchej Wody poza granicami topograficznymi zlewni Bystrej. Wody Goryczkowego Wywierzyska odznaczają się nieco niższymi stężeniami większości głównych jonów niż wody Wywierzysk Bystrej (tab. 1). Północna część zlewni Bystrej pokryta jest bielicami, które wykształciły się na utworach morenowych oraz rędzinami, które powstały na skałach węglanowych (Skiba i in. 2015).

Zlewnia Potoku Bystra cechuje się klimatem wysokogórskim z wyraźną piętrowością klimatyczno-roślinną. W reglu dolnym, do wysokości $1200 \mathrm{~m}$ n.p.m., występują zbiorowiska świerkowe, w piętrze regla górnego, do wysokości 1550 m n.p.m., dominuje bór świerkowy. Do wysokości 1800 m n.p.m. występuje piętro kosodrzewiny, powyżej której występuje piętro alpejskie $z$ dominacją muraw wysokogórskich (Mirkowa-Piękoś, Mirek 1996). Według Hessa (1996) w zlewni Potoku Bystra można wyróż- 
nić piętra klimatyczne, które są w bezpośredni sposób powiązane z piętrami roślinnymi. Górna granica piętra hal nawiązuje do izotermy $-2^{\circ}$, górna granica piętra kosówki - do izotermy $0^{\circ}$, górna granica regla górnego sięga izotermy $+2^{\circ}$, a górna granica regla dolnego - do izotermy $+4^{\circ}$. Najwyższe opady są obserwowane w okresie letnim, a roczna suma opadów na Kasprowym Wierchu sięga 1800 mm (Hess 1996).

\section{Materiały i metody}

Badania terenowe przeprowadzono w czasie wezbrania roztopowo-opadowego $\mathrm{w}$ dniach od 4 do 30 kwietnia 2016 r. Próbki wód z Potoku Bystra i Goryczkowego Potoku pobierano automatycznym próbnikiem ISCO 6712 co 6 lub 8 godzin w zależności od dynamiki stanów wody (ogółem $\mathrm{n}=106$ ). Dodatkowo w okresie przedwezbraniowym pobrano po jednej próbce wody - co było związane $z$ sezonowym monitoringiem cech fizykochemicznych wody prowadzonym w ramach projektu badawczego w zlewni Potoku Bystra. Stan wody oraz przewodność elektrolityczną właściwą (PEW) mierzono sondą OTT ecoLog 800 Water Level Logger z częstotliwością co 10 minut. W laboratorium ${ }^{1}$ metodą chromatografii jonowej (DIONEX ICS- 2000) oznaczono stężenia jonów $\mathrm{Ca}^{2+}, \mathrm{Mg}^{2+}, \mathrm{Na}^{+}, \mathrm{K}^{+}, \mathrm{NH}_{4}{ }^{+}, \mathrm{HCO}_{3}{ }^{-}, \mathrm{SO}_{4}{ }^{2-}, \mathrm{Cl}^{-} \mathrm{i} \mathrm{NO}_{3}{ }^{-}$, $\mathrm{NO}_{2}{ }^{-}, \mathrm{PO}_{4}{ }^{3-}, \mathrm{Li}^{+}, \mathrm{F}^{-}, \mathrm{Br}$. Do interpretacji wybrano stężenia jonów: $\mathrm{Ca}^{2+}, \mathrm{Mg}^{2+}, \mathrm{Na}^{+}, \mathrm{K}^{+}, \mathrm{HCO}_{3}{ }^{-}, \mathrm{SO}_{4}{ }^{2-}$, $\mathrm{Cl}^{-} \mathrm{i} \mathrm{NO}_{3}{ }^{-}$. Pozostałe jony występowały $\mathrm{W}$ bardzo niskich stężeniach na granicy progu oznaczalności, dlatego nie podlegały dalszej interpretacji. Mineralizację ogólną wody policzono jako sumę wszystkich oznaczonych jonów. W związku z bardzo niską mineralizacją wody w badanym obszarze, nie było możliwe stosowanie powszechnej metody obliczania mineralizacji z przewodności elektrolitycznej właściwej, ponieważ byłoby to obarczone zbyt dużym błędem pomiarowym (Janiec 1997, Żelazny 2012).

Warunki meteorologiczne w czasie roztopów, takie jak temperatura powietrza, grubość pokrywy śnieżnej oraz suma opadów atmosferycznych zostały określone na podstawie danych pochodzących ze stacji meteorologicznych IMGW znajdujących się na Kasprowym Wierchu oraz w Zakopanem. W opracowaniu wykorzystano podstawowe miary statystyczne: miary położenia (np. średnia arytmetyczna, minimum, maksimum), miary dyspersji (współczynnik zmienności - Cv [\%]) i miary współzależności (współczynnik korelacji liniowej - r). Zgodność danych empirycznych $z$ rozkładem normalnym sprawdzono testem Kolmo-

\footnotetext{
Laboratorium Hydrologiczno-Chemiczne Instytutu Geografii i Gospodarki Przestrzennej Uniwersytetu Jagiellońskiego w Krakowie.
}

gorowa-Smirnowa. Następnie dane zostały zlogarytmowane, a do analiz przyjęto rozkłady o większej symetryczności (wartości współczynnika skośności bliższe zeru). Rozkłady zlogarytmowane zostały

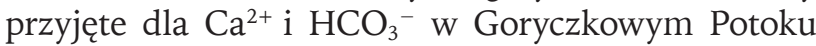
oraz $\mathrm{Cl}^{-}$i $\mathrm{NO}_{3}{ }^{-}$w zlewni Potoku Bystra. W potokach dokonano grupowania jonów na podstawie podobieństwa przebiegu zmian ich stężenia $\mathrm{w}$ czasie analizowanego wezbrania. Do obliczeń statystycznych użyto programów Statistica 13.1 i Grapher 13.

\section{Wyniki}

W dniach 4-30 kwietnia 2016 r. w Tatrach Polskich wystąpiło wezbranie roztopowo-deszczowe, które początkowo zostało wywołane wzrostem temperatury powietrza powyżej $0^{\circ} \mathrm{C}$, a po kilku dobach również - opadami deszczu (ryc. 2). Na Kasprowym Wierchu suma opadów w tym okresie wyniosła $146 \mathrm{~mm}$, przy czym maksymalna dobowa suma opadów wystąpiła 15 kwietnia - $34 \mathrm{~mm}$. Na stacji w Zakopanem suma opadów w tym okresie była niższa i wyniosła 100 $\mathrm{mm}$, a maksymalna dobowa suma opadów - $24 \mathrm{~mm}$. Średnia temperatura powietrza na Kasprowym Wierchu wynosiła $-0,2^{\circ} \mathrm{C}$; maksymalnie osiągnęła $7,2^{\circ} \mathrm{C}$ a minimalnie $-8,7^{\circ} \mathrm{C}$. Średnia temperatura powietrza w Zakopanem wynosiła $6,6^{\circ} \mathrm{C}$; maksymalnie osiągnęła $13,9^{\circ} \mathrm{C}$, a minimalnie $-0,5^{\circ} \mathrm{C}$ (ryc. 2). W ciągu miesiąca poprzedzającego wezbranie średnia dobowa temperatura utrzymywała się na poziomie poniżej $0^{\circ} \mathrm{C}$ (średnia miesięczna $=-5,8^{\circ} \mathrm{C}$ ), suma opadów atmosferycznych $\mathrm{w}$ formie śniegu wynosiła $76 \mathrm{~mm}$ (OGIMET 2018).

W Goryczkowym Potoku położonym w południowej, krystalicznej części zlewni Potoku Bystra stan

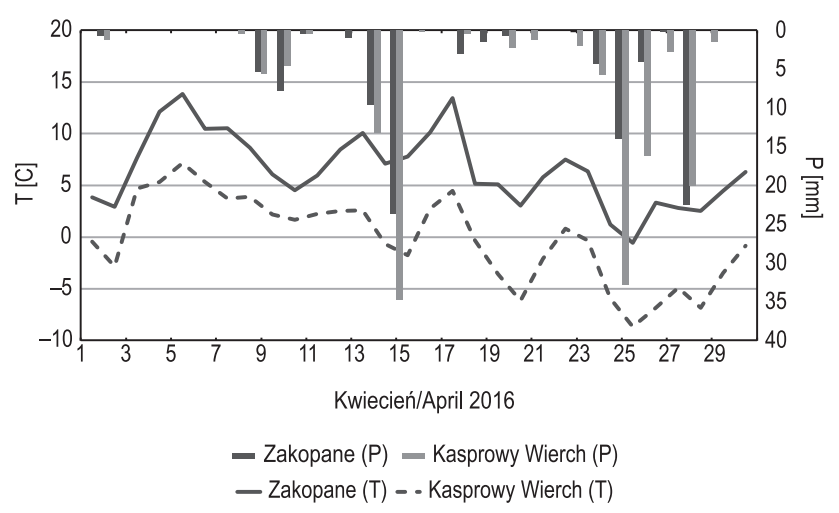

Ryc. 2. Przebieg temperatury powietrza (T) i opadów atmosferycznych (P) od 1 do 30 kwietnia 2016 r. na stacji meteorologicznej w Zakopanem i na Kasprowym Wierchu (na podstawie danych OGIMET 2018)

Fig. 2. Air temperature (T) and atmospheric precipitation (P) from 1 to 30 April 2016 at the Zakopane and Kasprowy Wierch gauging sites (based on data from OGIMET 2018) 
Tabela 2. Cechy fizykochemiczne badanych potoków w czasie analizowanego wezbrania - w dniach od 4 do 30 kwietnia 2016 r. ( $\bar{x}$ - średnia, Cv - współczynnik zmienności, r - współczynnik korelacji ze stanem wody)

Table 2. Physical and chemical data for the studied streams in the study period - from 04 to 30 April $2016(\overline{\mathrm{x}}-\mathrm{mean}, \mathrm{Cv}-$ coefficient of variation, $\mathrm{r}$ - coefficient of correlation with water levels)

\begin{tabular}{|c|c|c|c|c|c|c|c|c|c|c|}
\hline \multirow{3}{*}{ Cecha } & \multicolumn{5}{|c|}{ Goryczkowy Potok } & \multicolumn{5}{|c|}{ Potok Bystra } \\
\hline & Min & $\overline{\mathrm{x}}$ & Max & $\mathrm{Cv}$ & $r$ & Min & $\mathrm{x}$ & Max & $\mathrm{Cv}$ & $r$ \\
\hline & \multicolumn{3}{|c|}{$\left[\mathrm{mg} \mathrm{dm}^{-3}\right]$} & {$[\%]$} & {$[-]$} & \multicolumn{3}{|c|}{$\left[\mathrm{mg} \mathrm{dm}^{-3}\right]$} & {$[\%]$} & {$[-]$} \\
\hline Mineralizacja & 8,60 & 10,90 & 20,10 & 19,00 & 0,00 & 71,20 & 75,90 & 81,50 & 3,80 & 0,00 \\
\hline $\mathrm{Ca}^{2+}$ & 1,30 & 1,80 & 3,80 & 25,70 & $-0,09$ & 12,60 & 14,10 & 16,30 & 7,00 & $-0,30$ \\
\hline $\mathrm{Mg}^{2+}$ & 0,31 & 0,38 & 0,49 & 12,33 & $-0,39$ & 2,17 & 2,56 & 3,05 & 8,19 & $-0,75$ \\
\hline $\mathrm{Na}^{+}$ & 0,59 & 0,77 & 0,93 & 9,51 & $-0,96$ & 0,69 & 0,81 & 0,90 & 6,57 & $-0,49$ \\
\hline $\mathrm{K}^{+}$ & 0,18 & 0,20 & 0,25 & 5,97 & 0,36 & 0,29 & 0,33 & 0,39 & 7,04 & $-0,69$ \\
\hline $\mathrm{HCO}_{3}{ }^{-}$ & 3,00 & 4,40 & 11,00 & 32,90 & $-0,16$ & 46,70 & 51,20 & 57,00 & 5,20 & 0,45 \\
\hline $\mathrm{SO}_{4}{ }^{2-}$ & 1,84 & 2,11 & 2,34 & 5,65 & $-0,90$ & 3,78 & 4,50 & 5,28 & 9,66 & $-0,95$ \\
\hline $\mathrm{Cl}^{-}$ & 0,21 & 0,24 & 0,30 & 8,94 & 0,49 & 0,32 & 0,34 & 0,43 & 5,51 & 0,55 \\
\hline $\mathrm{NO}_{3}{ }^{-}$ & 0,46 & 0,99 & 1,44 & 18,05 & 0,37 & 1,89 & 2,01 & 2,52 & 6,32 & 0,62 \\
\hline
\end{tabular}

wody w czasie analizowanego wezbrania wzrósł od około $20 \mathrm{~cm} \mathrm{w}$ okresie przedwezbraniowym do 46 $\mathrm{cm}$ w czasie kulminacji wezbrania. Zmiany stężenia jonów w wodach potoku były wyraźne, szczególnie w przypadku jonów $\mathrm{HCO}_{3}{ }^{-}$i $\mathrm{Ca}^{2+}$. Świadczą o tym wysokie współczynniki zmienności $\mathrm{Cv}$, które wynosiły $32,9 \% \mathrm{w}$ przypadku $\mathrm{HCO}_{3}{ }^{-}$i $25,7 \% \mathrm{w}$ przypadku $\mathrm{Ca}^{2+}$ (tab. 2).

W Goryczkowym Potoku można wyróżnić trzy grupy jonów, w obrębie których zmiany stężenia $\mathrm{w}$ czasie analizowanego wezbrania były podobne. Pierwszą grupę stanowiły jony $\mathrm{Ca}^{2+}, \mathrm{Mg}^{2+} \mathrm{i}_{\mathrm{HCO}_{3}}{ }^{-}$. Ich stężenia były wysokie na początku wezbrania, jednak w miarę wzrostu fali wezbraniowej gwałtownie spadały osiągając minimalne wartości w czasie kulminacji wezbrania. W czasie opadania fali wezbraniowej stężenia $\mathrm{Ca}^{2+}, \mathrm{Mg}^{2+} \mathrm{i} \mathrm{HCO}_{3}{ }^{-}$stopniowo wzrastały. Zmiany stężenia $\mathrm{Ca}^{2+}, \mathrm{Mg}^{2+} \mathrm{i}_{\mathrm{HCO}_{3}}^{-}$ przyjmowały formę histerez zgodnych $z$ ruchem wskazówek zegara, tzn. przy takich samych stanach wody wyższe stężenia występowały w czasie wzrostu fali wezbraniowej niż w czasie jej spadku (ryc. 3, 4). Współczynnik korelacji stężenia jonów $\mathrm{Ca}^{2+}, \mathrm{Mg}^{2+}$ i $\mathrm{HCO}_{3}{ }^{-}$i stanu wody w Goryczkowym Potoku był bardzo słaby ujemny lub nieistotny (tab. 2).

Kolejną grupę jonów o podobnych zmianach stężenia w czasie wezbrania w Goryczkowym Potoku stanowiły jony $\mathrm{Na}^{+} \mathrm{i} \mathrm{SO}_{4}{ }^{2-}$. Zmiany ich stężenia bardzo wyraźnie nawiązywały do zmian stanów wody, które można opisać relacją: im wyższy stan wody tym niższe ich stężenie. Potwierdzają to wysokie, ujemne współczynniki korelacji stężenia tych jonów ze stanami wody: $\mathrm{r}=-0,96 \mathrm{w}$ przypadku $\mathrm{Na}^{+}$i $\mathrm{r}=-0,90$ $\mathrm{W}$ przypadku $\mathrm{SO}_{4}{ }^{2-}$. Związek pomiędzy stężeniem tych jonów, a stanem wody przybierał formę bardzo wąskiej histerezy, tzn. ich stężenie przy takich samych stanach wody było podobne w czasie wznoszenia i opadania fali wezbraniowej (ryc. 3, 4).
Trzecią grupę jonów, które odznaczały się podobnymi zmianami stężenia w wodach Goryczkowego Potoku w czasie analizowanego wezbrania były jony $\mathrm{Cl}^{-}, \mathrm{NO}_{3}{ }^{-} \mathrm{i} \mathrm{K} \mathrm{K}^{+}$. Ich stężenia były stosunkowo wysokie na początku wezbrania, po czym malały zarówno w czasie wzrostu jak i spadku fali wezbraniowej. Związek stężenia tych jonów ze stanami wody przyjmował formę szerokich, otwartych histerez o zwrocie na ogół zgodnym $z$ ruchem wskazówek zegara (ryc. 3, 4).

W Potoku Bystra, w przekroju wodowskazowym zlokalizowanym $\mathrm{w}$ dolnej, osadowej części zlewni w czasie analizowanego wezbrania stan wody wzrósł o około $20 \mathrm{~cm}$. W potoku tym średnie stężenia większości jonów były wielokrotnie wyższe niż w Goryczkowym Potoku (tab. 2). Zmiany stężenia jonów były jednak mniej wyraźne niż w Goryczkowym Potoku, na co wskazują niższe współczynniki zmienności $C v$, które w przypadku żadnego jonu nie przekroczyły $10 \%$ (tab. 2). W czasie trwania wysokich stanów wody w Potoku Bystra wyraźnie obniżyły się stężenia jonów $\mathrm{K}^{+}, \mathrm{SO}_{4}{ }^{2-}, \mathrm{Ca}^{2+}$ i $\mathrm{Mg}^{2+}$, natomiast wzrosły stężenia jonów $\mathrm{HCO}_{3}{ }^{-}, \mathrm{Cl}^{-}$i $\mathrm{NO}_{3}^{-}$(ryc. 5, 6). Stężenia jonów $\mathrm{Na}^{+}$nie uległy zmianie. $\mathrm{W}$ przypadku jonów $\mathrm{Ca}^{2+} \mathrm{i} \mathrm{Mg}^{2+}$, pomimo ogólnej wyraźnej tendencji spadkowej, w trakcie wzrostu fali wezbraniowej, zaobserwowano chwilowy wyraźny wzrost stężenia tych jonów, który na rycinie 5 zaznaczono literą A.

Przebieg zmian stężenia większości jonów wraz ze zmianami stanu wody w Potoku Bystra był bardziej skomplikowany niż w Goryczkowym Potoku (ryc. 5). W przypadku $\mathrm{Ca}^{2+}, \mathrm{Mg}^{2+} \mathrm{i} \mathrm{K}^{+}$histerezy przyjmowały zwrot zgodny z ruchem wskazówek zegara, w przypadku $\mathrm{Na}^{+} \mathrm{i} \mathrm{SO}_{4}{ }^{2-}$ przeciwny do ruchu wskazówek zegara. W przypadku pozostałych jonów, zmiany ich stężenia były na tyle nieregularne, że uniemożliwiały wskazanie jednoznacznych zwrotów histerez (ryc. 6). 


\section{Goryczkowy Potok}
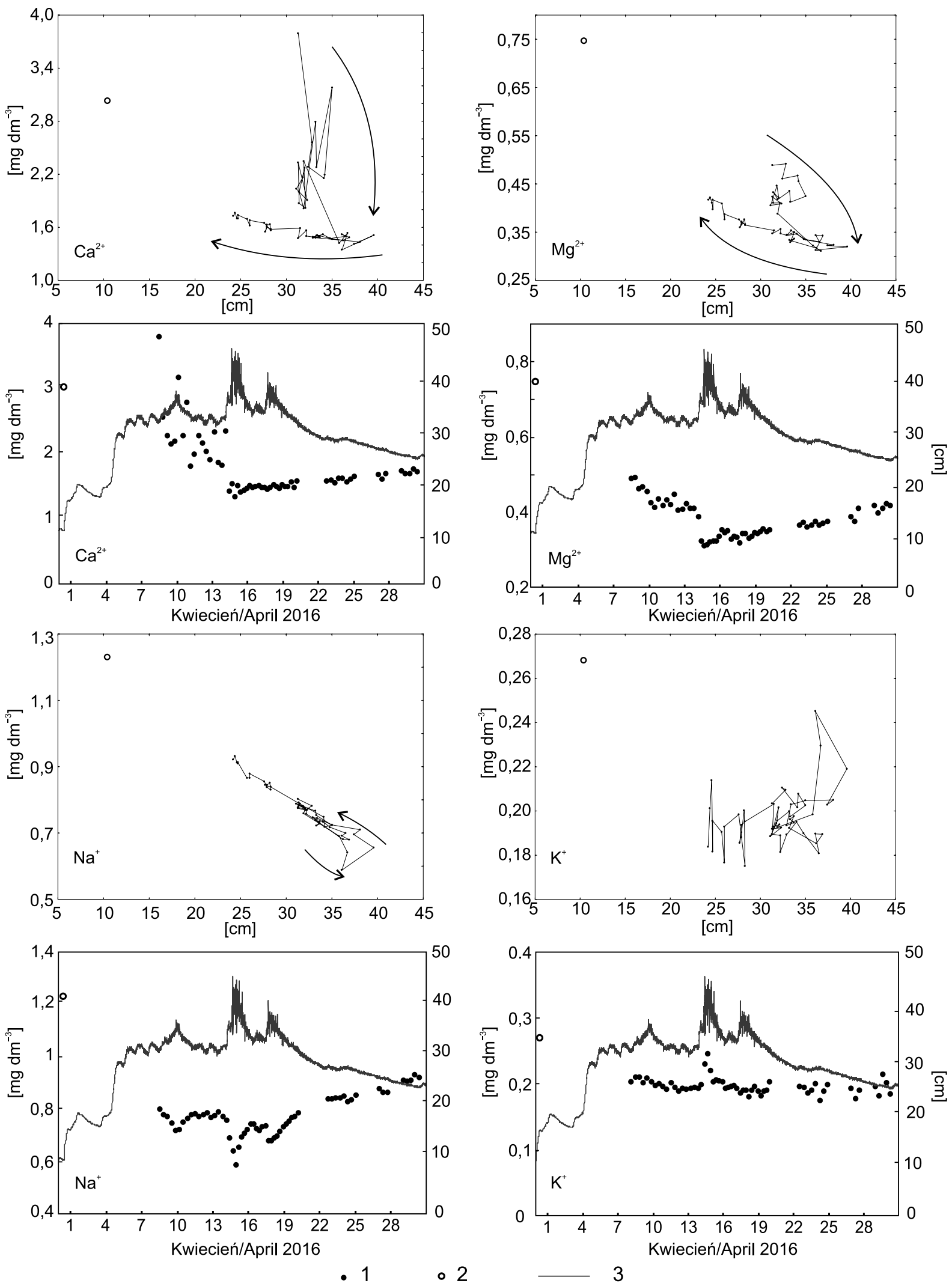

Ryc. 3. Stężenia jonów $\mathrm{Ca}^{2+}, \mathrm{Mg}^{2+}, \mathrm{Na}^{+}$i K ${ }^{+}$w Goryczkowym Potoku w czasie wezbrania w dniach 4-30 kwietnia 2016 r. 1 - stężenie jonów w czasie wezbrania, 2 - stężenie jonów przed wezbraniem, 3 - stan wody

Fig. 3. Concentrations of the $\mathrm{Ca}^{2+}, \mathrm{Mg}^{2+}, \mathrm{Na}^{+}$and $\mathrm{K}^{+}$ions in Goryczkowy Stream during event from 4 to 30 April 2016 1 - ion concentration during event, 2 - ion concentration before event, 3 - water level 
Goryczkowy Potok
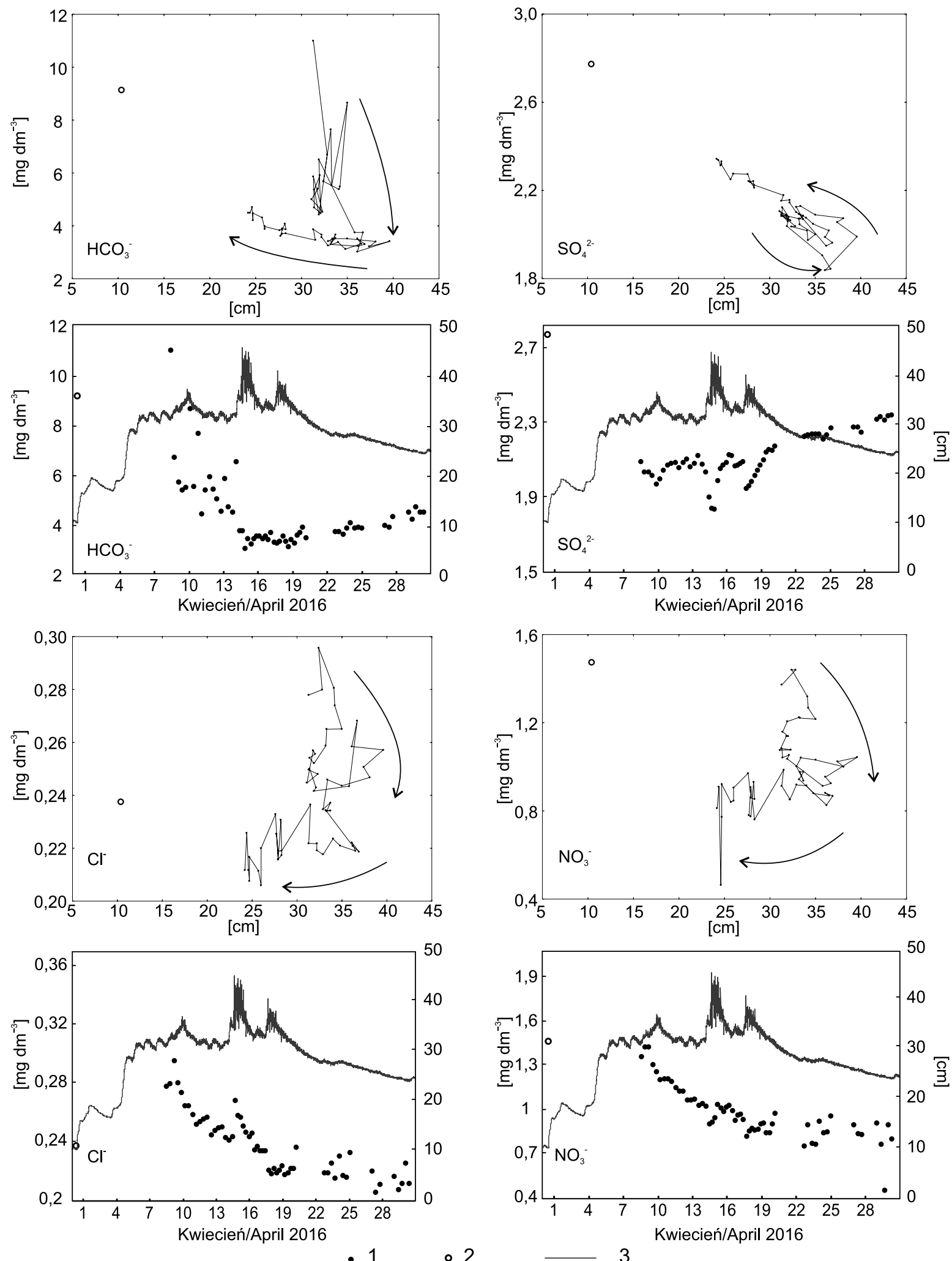

Ryc. 4. Stężenia jonów $\mathrm{HCO}_{3}{ }^{-}, \mathrm{SO}_{4}{ }^{2-}, \mathrm{Cl}^{-} \mathrm{i} \mathrm{NO}{ }^{-}{ }^{-} \mathrm{W}$ Goryczkowym Potoku w czasie wezbrania w dniach 4-30 kwietnia $2016 \mathrm{r}$.

1 - stężenie jonów w czasie wezbrania, 2 - stężenie jonów przed wezbraniem, 3 - stan wody

Fig. 4. Concentration of the $\mathrm{HCO}_{3}{ }^{-}, \mathrm{SO}_{4}{ }^{2-}, \mathrm{Cl}^{-}$and $\mathrm{NO}_{3}$ ions in Goryczkowy Stream during event from 4 to 30 April 2016 1 - ion concentration during event, 2 - ion concentration before event, 3 - water level 


\section{Potok Bystra}
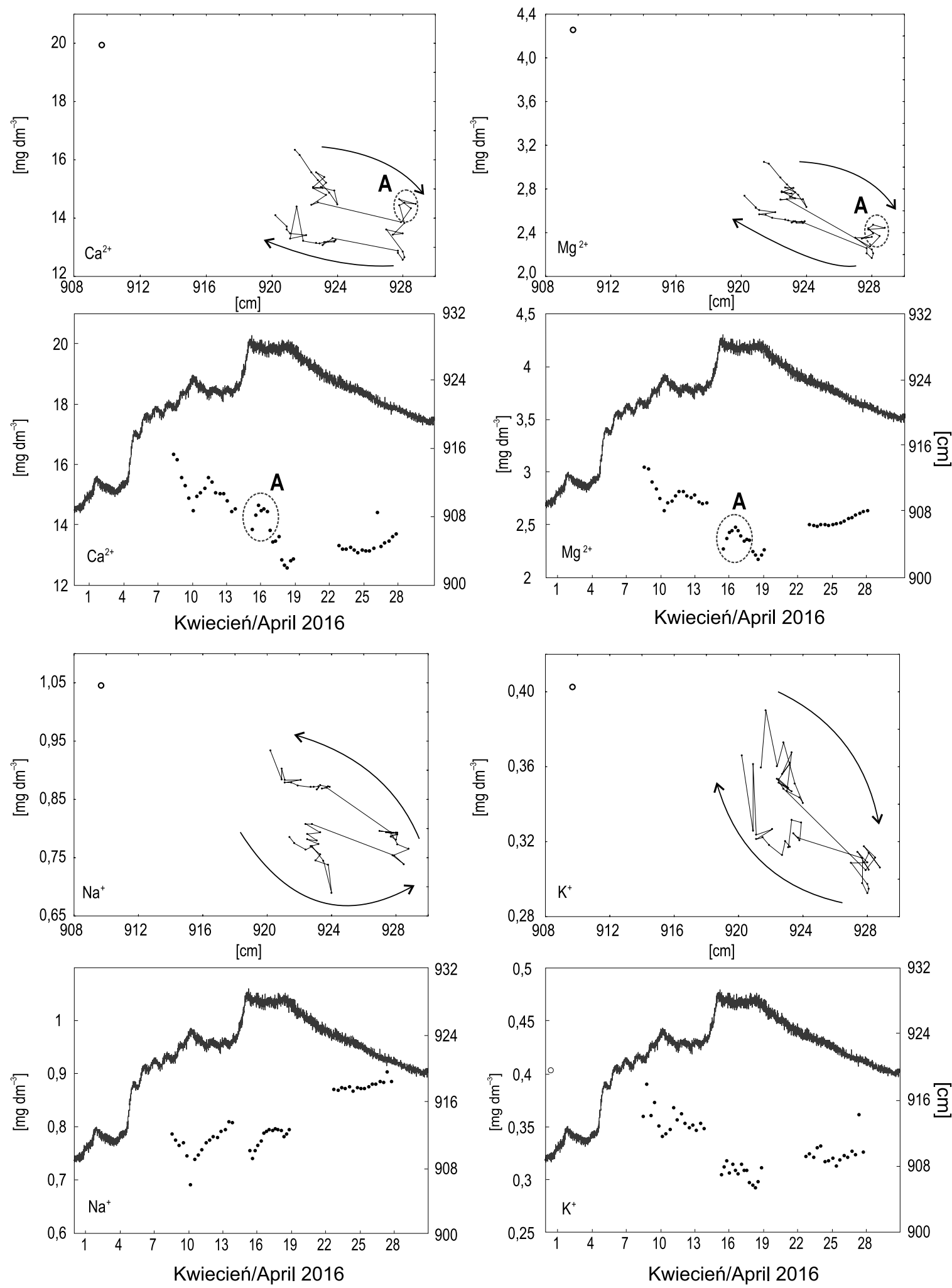

- 1

$\circ 2$

3

Ryc. 5. Stężenia jonów $\mathrm{Ca}^{2+}, \mathrm{Mg}^{2+}, \mathrm{Na}^{+} \mathrm{i} \mathrm{K}^{+} \mathrm{w}$ Potoku Bystra w czasie analizowanego wezbrania w dniach 4-30 kwietnia 2016 r.

1 - stężenie jonów w czasie wezbrania, 2 - stężenie jonów przed wezbraniem, 3 - stan wody

Fig. 5. Concentrations of the $\mathrm{Ca}^{2+}, \mathrm{Mg}^{2+}, \mathrm{Na}^{+}$and $\mathrm{K}^{+}$ions in Bystra Stream during event from 4 to 30 April 2016 1 - ion concentration during event, 2 - ion concentration before event, 3 - water level 
Potok Bystra
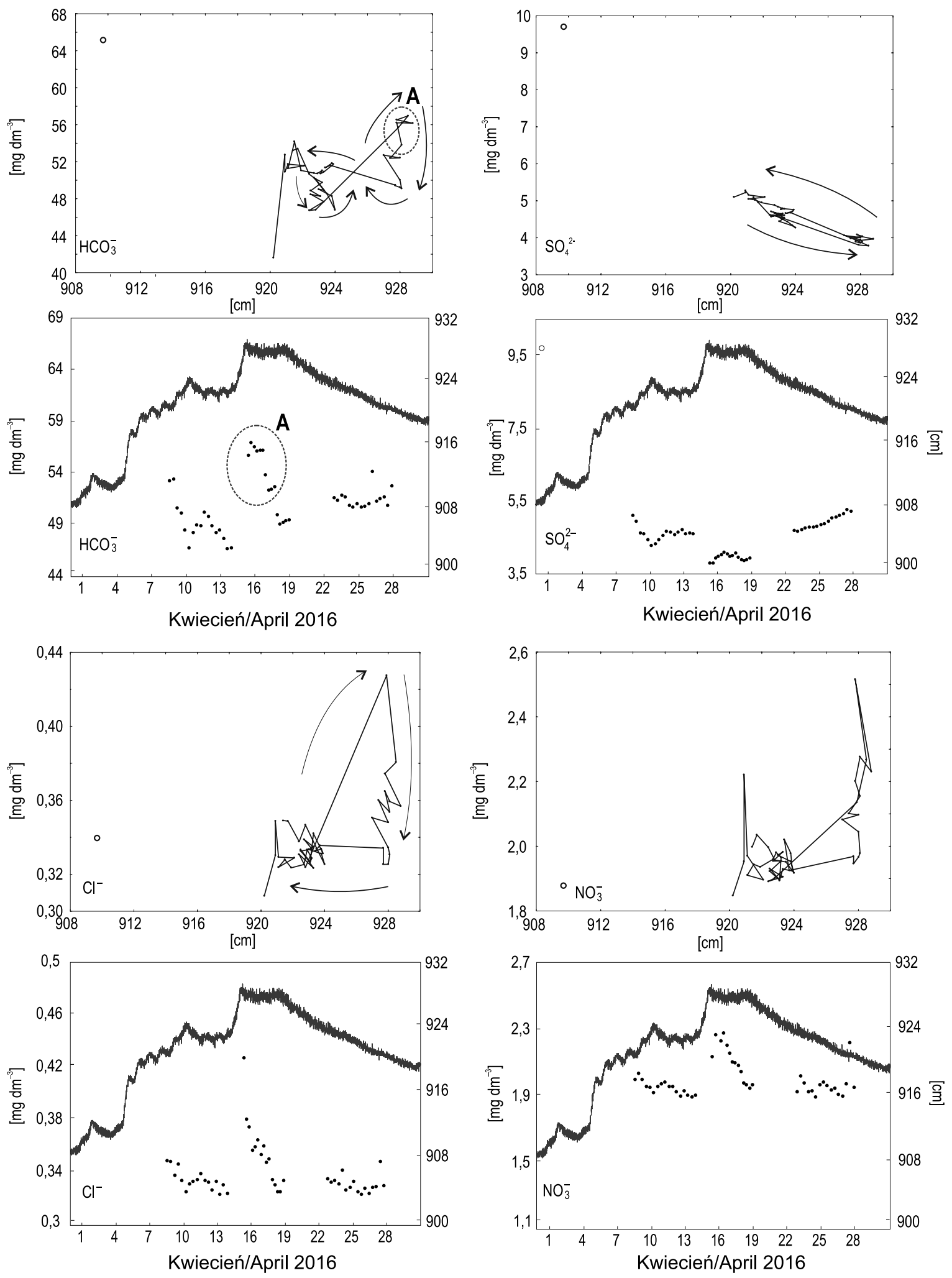

- 1 ० 2

3

Ryc. 6. Stężenia jonów $\mathrm{HCO}_{3}{ }^{-}, \mathrm{SO}_{4}{ }^{2-}, \mathrm{Cl}^{-} \mathrm{i} \mathrm{NO}_{3} \mathrm{w}$ Potoku Bystra w czasie analizowanego wezbrania w dniach 4-30 kwietnia 2016 r.

1 - stężenie jonów w czasie wezbrania, 2 - stężenie jonów przed wezbraniem, 3 - stan wody

Fig. 6. Concentrations of the $\mathrm{HCO}_{3}{ }^{-}, \mathrm{SO}_{4}{ }^{2-}, \mathrm{Cl}^{-}$and $\mathrm{NO}_{3}$ ions in Bystra Stream during event from 4 to 30 April 2016 1 - ion concentration during event, 2 - ion concentration before event, 3 - water level 


\section{Dyskusja}

Wysokie stężenia $\mathrm{Ca}^{2+}, \mathrm{Mg}^{2+} \mathrm{i} \mathrm{HCO}_{3}{ }^{-}$w wodach Goryczkowego Potoku na początku wezbrania związane były najprawdopodobniej z przemywaniem przez wody śródpokrywowe płytkich gleb (rankery, gleby inicjalne, bielice), pokrywających krystaliczną część zlewni Potoku Bystra (Skiba i in. 2015). Szybki spadek stężenia tych jonów we wznoszącej fazie wezbrania świadczy o ich niewielkich zasobach $w$ glebach oraz o szybkim krążeniu wody w zlewni w okresie roztopowym, co jest charakterystyczne dla małych zlewni górskich (Klein 1981). Drugim potencjalnym źródłem dostawy jonów $\mathrm{Ca}^{2+}, \mathrm{Mg}^{2+}$ i $\mathrm{HCO}_{3}{ }^{-}$do koryta potoku na początku wezbrania mogłyby być wody $z$ topniejącej pokrywy śnieżnej, jednak bardzo niskie średnie stężenie tych jonów w pokrywie śnieżnej (tab. 3) wyklucza taką możliwość. Na dostawę tych jonów z gleby na początku wezbrania wskazuje także wysoki udział w wodach Goryczkowego Potoku jonów $\mathrm{Ca}^{2+} \mathrm{i} \mathrm{HCO}_{3}{ }^{-} \mathrm{W}$ stosunku do jonu i $\mathrm{SO}_{4}{ }^{2-}$ (ryc. 7). Jon $\mathrm{SO}_{4}{ }^{2-}$ stanowi ważną część składu chemicznego wód opadowych (tab. 3). Wraz ze wzrostem fali wezbraniowej i szybkim wyczerpywaniem się zasobów $\mathrm{Ca}^{2+} \mathrm{i} \mathrm{HCO}_{3}{ }^{-} \mathrm{W}$ glebach, udział jonów $\mathrm{HCO}_{3}{ }^{-} \mathrm{W}$ wodach Goryczkowego Potoku malał - a $\mathrm{SO}_{4}{ }^{2-}$ wzrastał
Tabela 3. Stężenia wybranych jonów w pokrywie śnieżnej w lutym 2016 r. ( $n=15)$

Table 3. Concentration of selected ions in snow cover in February $2016(n=15)$

\begin{tabular}{cc}
\hline Jon & Stężenie $\left[\mathrm{mg} \mathrm{dm}^{-3}\right]$ \\
\hline $\mathrm{Ca}^{2+}$ & 0,16 \\
$\mathrm{Mg}^{2+}$ & 0,03 \\
$\mathrm{Na}^{+}$ & 0,03 \\
$\mathrm{~K}^{+}$ & 0,05 \\
$\mathrm{HCO}_{3}{ }^{-}$ & 0,39 \\
$\mathrm{SO}_{4}{ }^{-}$ & 0,70 \\
$\mathrm{Cl}^{-}$ & 0,16 \\
$\mathrm{NO}_{3}{ }^{-}$ & 0,75 \\
\hline
\end{tabular}

(ryc. 7). Skład chemiczny wód Goryczkowego Potoku kształtowany był przez proces rozcieńczania dostawą nisko zmineralizowanych wód $z$ topniejącej pokrywy śnieżnej. Podobne zjawisko zaobserwowała Siwek (2012) w małej zalesionej zlewni na Pogórzu Karpackim w czasie wezbrania rozlewnego. Stopniowy wzrost stężenia $\mathrm{Ca}^{2+}$, $\mathrm{Mg}^{2+}$ i $\mathrm{HCO}_{3}{ }^{-}$w czasie opadania fali wezbraniowej wskazuje na to, że kolejnym

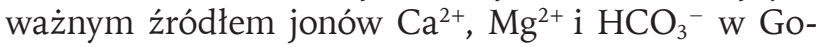
ryczkowym Potoku były wody podziemne. Różne źródła dostawy jonów $\mathrm{Ca}^{2+}, \mathrm{Mg}^{2+}$ i $\mathrm{HCO}_{3}{ }^{-}$do koryta Goryczkowego Potoku w czasie wezbrania, odznacza-

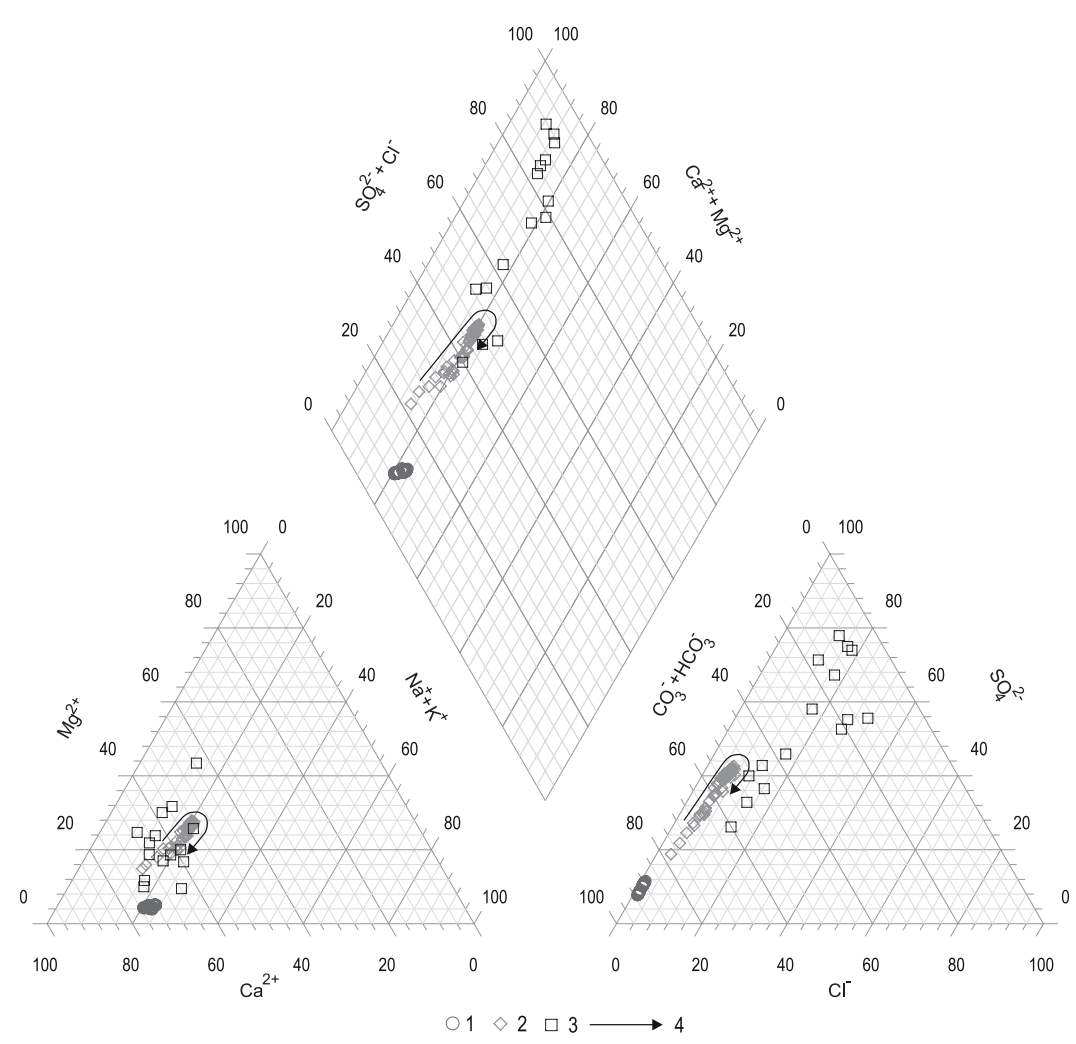

Ryc. 7. Udział głównych jonów w wodach Goryczkowego Potoku i Potoku Bystra w czasie analizowanego wezbrania oraz w pokrywie śnieżnej w $2016 \mathrm{r}$.

1 - Potok Bystra, 2 - Goryczkowy Potok, 3 - śnieg, 4 - kierunek zmian w czasie wezbrania

Fig. 7. Share of main ions in the waters of Goryczkowy Stream and Bystra Stream during analysed event and in snow cover in 2016

1 - Bystra Stream, 2 - Goryczkowy Stream, 3 - snow, 4 - direction of change during event 
jące się różnymi stężeniami powodowały, że związek między stężeniem $\mathrm{Ca}^{2+}, \mathrm{Mg}^{2+} \mathrm{i} \mathrm{HCO}_{3}{ }^{-}$a stanem wody był na ogół słaby.

Wysokie ujemne współczynniki korelacji stężenia $\mathrm{SO}_{4}{ }^{2-}$, a także $\mathrm{Na}^{+}$ze stanami wody w Goryczkowym Potoku wskazują na jedno główne geologiczne źródło tych jonów w zlewni. Zmiany stężenia tych dwóch jonów są typowe dla procesu rozcieńczania wód podziemnych wodami roztopowymi zasilającymi potok drogą spływu powierzchniowego i śródpokrywowego. Wydaje się jednak, że wody roztopowe są także źródłem jonów $\mathrm{SO}_{4}{ }^{2-} \mathrm{W}$ Goryczkowym Potoku. Dowodzi tego wysoki udział tych jonów (ryc. 7) w składzie chemicznym wód potoku w czasie najwyższych przepływów.

Wysokie stężenia jonów $\mathrm{Cl}^{-}, \mathrm{NO}_{3}{ }^{-}$w Goryczkowym Potoku na początku analizowanego wezbrania roztopowo-deszczowego świadczą o ich dostawie do koryta wraz z wodami roztopowymi przemywającymi pokrywy glebowe oraz $z$ wodami spływu śródpokrywowego. Stężenia $\mathrm{Cl}^{-}, \mathrm{NO}_{3}^{-}{ }^{-} \mathrm{K}^{+} \mathrm{W}$ wodach potoku były nieco wyższe niż w pokrywie śnieżnej. Spadek stężenia tych jonów w czasie opadania fali wezbraniowej świadczy o małej zasobności podłoża geologicznego $\mathrm{w}$ te pierwiastki.

Ze względu na złożone zasilanie północnej osadowej części zlewni Potoku Bystra, związek stężenia większości jonów ze stanami wody był bardziej skomplikowany niż w Goryczkowym Potoku (różnokierunkowe histerezy). Najbardziej wyraźny spadek stężenia jonów wraz ze wzrostem stanów wody, świadczący
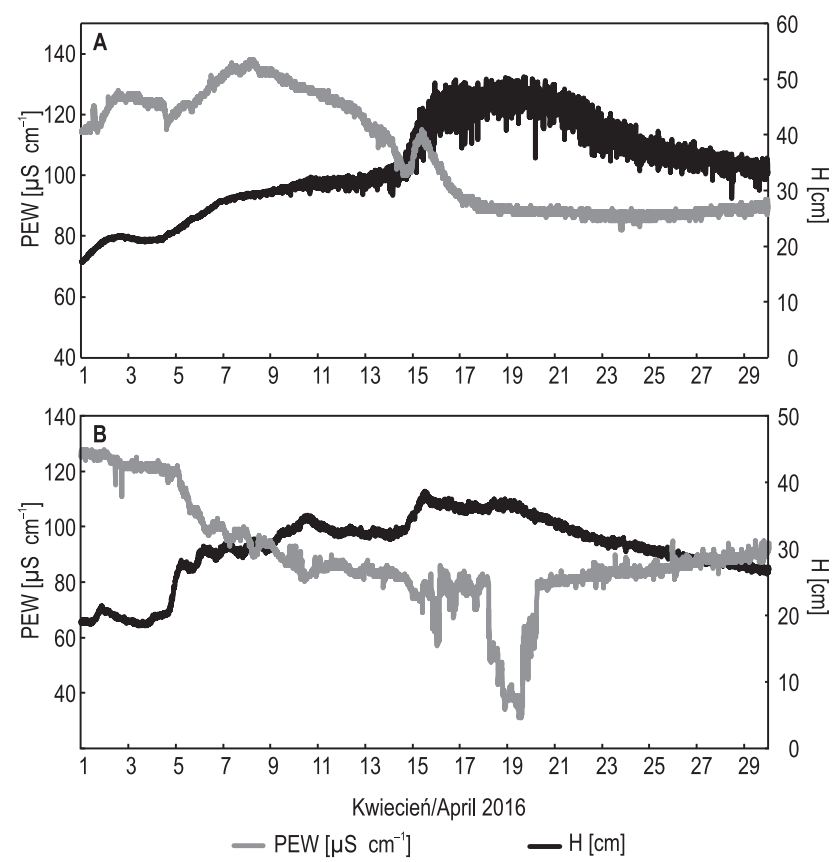

Ryc. 8. Wywierzysko Bystrej Górne (A) oraz Goryczkowe (B) PEW - przewodność elektrolityczna właściwa, $\mathrm{H}$ - stan wody

Fig. 8. Bystra Górne (A) and Goryczkowe (B) karst spring PEW - specific electrical conductivity, $\mathrm{H}$ - water levels o procesie rozcieńczania, występował $\mathrm{w}$ przypadku jonów $\mathrm{Mg}^{2+} \mathrm{i} \mathrm{SO}_{4}{ }^{2-}$. Zmiany stężenia jonów w Potoku Bystra w trakcie wezbrania roztopowego sugerują, że oprócz procesu rozcieńczania wód potoku wodami roztopowymi, w trakcie trwania najwyższych przepływów mogło dojść do bezpośredniego dopływu wód Goryczkowego Potoku do koryta Wywierzyska Goryczkowego. O tym, że takie zjawisko pojawia się epizodycznie świadczy istnienie suchego koryta w środkowej części zlewni Bystrej w lesie pomiędzy strefą ponorów Goryczkowego Potoku a Goryczkowym Wywierzyskiem (ryc. 1). Potwierdza to również wyraźny spadek przewodności w wodach Goryczkowego Wywierzyska w czasie najwyższych stanów wód (ryc. 8). W czasie wysokich stanów wody, część wód Goryczkowego Potoku nie zostaje wchłonięta w strefie ponorowej i epizodycznym korytem dopływa do Goryczkowego Wywierzyska. W czasie trwania wysokich stanów wody w Potoku Bystra wyraźnie spadały stężenia tych jonów, które w Goryczkowym Potoku, odwadniającym zlewnię krystaliczną, występowały w bardzo niskich stężeniach $\left(\mathrm{K}^{+}, \mathrm{SO}_{4}{ }^{2-}, \mathrm{Ca}^{2+}, \mathrm{Mg}^{2+}\right)$. Nie ulegały natomiast zmianie stężenia jonów, które w obu potokach występują w porównywalnych stężeniach (np. $\mathrm{Na}^{+}$). W czasie trwania wysokich stanów wody wyraźnie wzrosły stężenia $\mathrm{Cl}^{-}$i $\mathrm{NO}_{3}{ }^{-}$, co mogło być związane $z$ dostawą do Potoku Bystra wód Goryczkowego Potoku wzbogaconych $\mathrm{w}$ te jony w czasie przepływu przez teren zalesiony.

Nietypowym zjawiskiem zaobserwowanym w Potoku Bystra w czasie analizowanego wezbrania był wzrost stężenia $\mathrm{HCO}_{3}{ }^{-}$wraz ze wzrostem stanów wody. W czasie podwyższonych stanów wody w okresie roztopowym oczekiwany jest spadek stężenia $\mathrm{HCO}_{3}{ }^{-}$. Wzrost $\mathrm{HCO}_{3}{ }^{-}$wynika prawdopodobnie z faktu „wypchnięcia” silniej zmineralizowanych wód $z$ systemu wywierzysk Bystrej, na co wskazywałby wzrost przewodności wody w wywierzysku Bystrej Górnym (ryc. 8). W warunkach mocno nawodnionego masywu górskiego woda zalegająca w kanałach krasowych może być z nich „wypchnięta” przez wody opadowe dostające się do ośrodka skalnego. Podobne zjawisko było obserwowane w źródłach krasowych w Szwajcarii przez Perrina i in. (2007), którzy również odnotowali wzrost stężenia $\mathrm{HCO}_{3}{ }^{-}$W czasie wezbrania roztopowego. Wzrost ten również wiązali $z$ wypchnięciem wody $z$ kanałów krasowych, na skutek ciśnienia wywieranego przez dopływające do systemu krasowego wody opadowe. Wyrzut wody o podwyższonej przewodności $\mathrm{z}$ wywierzysk Bystrej był najprawdopodobniej także przyczyną chwilowego, ale wyraźnego wzrostu stężenia jonów $\mathrm{Ca}^{2+} \mathrm{i} \mathrm{Mg}^{2+} \mathrm{w}$ Potoku Bystra w trakcie wzrostu fali wezbraniowej, co jest oznaczone literą A na rycinie 5. Wzrost ten zbiegł się $\mathrm{w}$ czasie $\mathrm{z}$ intensywnymi opadami deszczu, które na Kasprowym Wierchu wyniosły $34 \mathrm{~mm}$ a w Zakopanem $24 \mathrm{~mm}$. 


\section{Podsumowanie}

Głównym procesem kształtującym zmiany składu chemicznego wód w czasie wezbrania roztopowo-deszczowego w zlewni zbudowanej wyłącznie ze skał krystalicznych (zlewnia Goryczkowego Potoku) oraz w zlewni zbudowanej zarówno ze skał krystalicznych jak i skał osadowych z rozbudowanymi systemami krasowymi (zlewnia Potoku Bystra) był proces rozcieńczania wód podziemnych nisko zmineralizowanymi wodami roztopowymi i deszczowymi. Przejawiało się to spadkiem stężenia większości jonów w potokach wraz ze wzrostem stanów wody. W Goryczkowym Potoku (zlewnia krystaliczna) proces rozcieńczania był najbardziej wyraźny w przypadku jonów $\mathrm{Na}^{+} \mathrm{i} \mathrm{SO}_{4}{ }^{2-}$ natomiast $\mathrm{w}$ Potoku Bystra (zlewnia osadowa) - w przypadku jonów $\mathrm{Mg}^{2+}$ i $\mathrm{SO}_{4}{ }^{2-}$. W przypadku pozostałych jonów proces rozcieńczania był modyfikowany innymi procesami zachodzącymi w zlewni. W Goryczkowym Potoku (zlewnia krystaliczna) krótkotrwały wzrost stężenia niektórych jonów, jak np. $\mathrm{Ca}^{2+}, \mathrm{Mg}^{2+}, \mathrm{HCO}_{3}{ }^{-}$, $\mathrm{Cl}^{-}, \mathrm{NO}_{3}^{-}$, na początku wezbrania spowodowany był ich wymywaniem z płytkich pokryw glebowych przez wody spływu śródpokrywowego. W Potoku Bystra (zlewnia krasowa), w czasie wysokich stanów wód, proces rozcieńczania modyfikowany był natomiast wypchnięciem silniej zmineralizowanych „starszych" wód z systemów krasowych. Przejawiało się to między innymi wzrostem stężenia $\mathrm{HCO}_{3}{ }^{-}$ wraz ze wzrostem stanów wody, co jest zjawiskiem bardzo rzadko spotykanym w wodach rzecznych w czasie wezbrań. W trakcie wezbrania skład chemiczny wód Potoku Bystra był kształtowany także epizodycznym dopływem wód Goryczkowego Potoku z południowej, krystalicznej części zlewni, które nie zostały wchłonięte przez strefę ponorów. Wody te wykorzystywały znajdujące się poniżej strefy ponorów suche koryto Goryczkowego Potoku i docierały nim bezpośrednio do Wywierzyska Goryczkowego, które jest jednym z trzech głównych źródeł Potoku Bystra.

\section{Podziękowania}

Badania zostały wykonane $\mathrm{w}$ ramach projektu: Monitoring hydrologiczno-chemiczny w górnej części Doliny Bystrej i Suchej Wody (KDU_000281). Projekt finansowany przez Polskie Koleje Linowe. Składamy serdeczne podziękowania recenzentom oraz edytorowi za krytyczne uwagi i cenne wskazówki.

\section{Wkład autorów}

Monika Sajdak: 60\%, Joanna Siwek: 20\%, Mirosław Żelazny: 15\%, Izabela Dojtrowska: $5 \%$.

\section{Literatura}

Abesser C., Robinson R., Soulsby C., 1996. Iron and manganese cycling in the storm runoff of a Scottish upland catchment. Journal of Hydrology 326(1): 59-78. DOI: 10.1016/j.jhydrol.2005.10.034.

Barczyk G., 2008. Tatrzańskie wywierzyska: krasowe systemy wywierzyskowe Tatr Polskich. Wydawnictwa Tatrzańskiego Parku Narodowego, Zakopane: 1-178.

Bazemore D.E., Eshleman K.N., Hollenback K.J., 1994. The role of soil water in stormflow generation in a forested headwater catchment: synthesis of natural tracer and hydrometric. Journal of Hydrology 162(1-2): 47-75. DOI: 10.1016/00221694(94)90004-3.

Caissie D., Pollock T.L., Cunjak R.A., 1996. Variation in stream water chemistry and hydrograph separation in a small drainage basin. Journal of Hydrology 178(1-4): 137-157. DOI: 10.1016/0022-1694(95)02806-4.

Cameron E.M., 1996. Hydrogeochemistry of the Fraser River, British Columbia: seasonal variation in major and minor components. Journal of Hydrology 182(1-4): 206-225. DOI: 10.1016/0022-1694(95)02924-9.

Dąbrowski T., Głazek J., 1968. Badania przepływów krasowych we wschodniej części Tatr Polskich. Speleologia 3(2): 85-98.

Edwards A.M.C., 1973. The variation of dissolved constituents with discharge in some Norfolk Rivers. Journal of Hydrology 18(3-4): 219-242. DOI: 10.1016/0022-1694(73)90049-8.

Foster I.D.L., 1978. A multivariate model of storm-period solute behaviour. Journal of Hydrology 39(3-4): 339-353. DOI: 10.1016/0022-1694(78)90010-0.

Froehlich W., 1982. Mechanizm transportu fluwialnego i dostawy zwietrzelin do koryta w górskiej zlewni fliszowej. Prace Geograficzne IGiPZ PAN 143: 1-144.

Gromadzka M., Wolanin A., Żelazny M., Pęksa Ł., 2015. Physical and chemical properties of the Goryczkowe and Bystrej Górne vaucluse springs in the Tatra Mountains. Hydrology Research 46(6): 954-968. DOI: 10.2166/nh.2015.136.

Hess M., 1996. Klimat. W: Z. Mirek, Z. Głowaciński, K. Klimek, H. Piękoś-Mirkowa (red.), Przyroda Tatrzańskiego Parku Narodowego, Tatry i Podtatrze 3, Tatrzański Park Narodowy, KrakówZakopane: $53-68$.

Hinton M.J., Schiff S.L., English M.C., 1994. Examining the contributions of glacial till water to storm runoff using two- and three-component hydrograph separations. Water Resources Research 30(4): 983-993. DOI: 10.1029/93WR03246.

Holloway J.M., Dahlgren R.A., 2001. Seasonal and event-scale variations in solute chemistry for four Sierra Nevada catchments. Journal of Hydrology 250(1-4): 106-121. DOI: 10.1016/S00221694(01)00424-3.

Janiec B., 1997. Transformacje i translokacje jonowe w wodach naturalnych Roztocza Zachodniego. Wydawnictwo UMCS, Lublin, Rozprawy Habilitacyjne 57: 1-214.

Kendall K.A., Shanley J.B., McDonnell J.J., 1999. A hydrometric and geochemical approach to test the transmissivity feedback hypothesis during snowmelt. Journal of Hydrology 219(3-4): 188-205. DOI: 10.1016/S0022-1694(99)00059-1.

Klein M., 1981. Dissolved material transport - the flushing effect in surface and subsurface flow. Earth Surface Processes and Landforms 6.2: 173-178. DOI: 10.1002/esp.3290060210

Klimaszewski M., 1988. Rzeźba Tatr Polskich. PWN, Warszawa: $1-668$.

Kondracki J., 2002. Geografia regionalna Polski. PWN, Warszawa: $1-440$.

Kostrzewski A., Mazurek M., Stach A., Zwoliński Zb., 1992. Hydrochemiczna interpretacja przepływów wezbraniowych w zlewniach młodoglacjalnych. W: A.Kostrzewski, M.Pulina (red.), Metody hydrochemiczne w geomorfologii dynamicznej, Wybrane problemy, Katowice: 127-142.

Kostrzewski A., Mazurek M., Zwolinski Zb., 1993. Sezonowa zmienność składu chemicznego wód górnej Parsęty (Pomorze 
Zachodnie) jako odzwierciedlenie funkcjonowania systemu zlewni. W: A.Kostrzewski (red.), Geoekosystem obszarów nizinnych. Zeszyty Naukowe - Polska Akademia Nauk. Komitet Naukowy przy Prezydium PAN „Człowiek i Środowisko” 6: 79-99.

Kostrzewski A., Mazurek M., Zwoliński Zb., 1994. Dynamika transportu fluwialnego górnej Parsęty jako odbicie funkcjonowania systemu zlewni. Stowarzyszenie Geomorfologów Polskich, Poznań: 1-165.

Krzemień K., 1991. Dynamika wysokogórskiego systemu fluwialnego na przykładzie Tatr Zachodnich. Uniwersytet Jagielloński, Kraków, Rozprawy Habilitacyjne 215: 1-160.

Laudon H., Seibert J., Köhler S., Bishop K., 2004. Hydrological flow paths during snowmelt: congruence between hydrometric measurements and oxygen 18 in meltwater, soil water, and runoff. Water Resources Research 40(3): 1-9. DOI: $10.1029 / 2003$ WR002455.

Małecka D. 1997. Źródła masywu tatrzańskiego. Acta Universitatis Lodziensis, Folia Geographica Physica 2: 9-26.

Małecka D., 1993. Hydrogeologia krasu tatrzańskiego. W: J.Grodzicki (red.), Jaskinie wschodniego zbocza Doliny Kościeliskiej. Jaskinie Tatrzańskiego Parku Narodowego 3, Polskie Towarzystwo Przyjaciół Nauk o Ziemi, Tatrzański Park Narodowy, Warszawa: $11-35$.

Mazurek M., 2000. Zmienność transportu materiału rozpuszczonego w zlewni Kłudy jako przejaw współczesnych procesów denudacji chemicznej (Pojezierze Zachodnie). Wydawnictwo Naukowe UAM, Poznań, Seria Geografia 62: 1-124.

McGlynn B.L., McDonnell J.J., Shanley J.B., Kendall C., 1999. Riparian zone flowpath dynamics during snowmelt in a small headwater catchment. Journal of Hydrology 222(1-4): 75-92. DOI: 10.1016/S0022-1694(99)00102-X.

Mirkowa-Piękoś H., Mirek Z., 1996. Zbiorowiska roślinne. W: Z.Mirek, Z.Głowaciński, K.Klimek, H.Piękoś-Mirkowa (red.), Przyroda Tatrzańskiego Parku Narodowego, Tatry i Podtatrze 3, Tatrzański Park Narodowy, Kraków-Zakopane: 237-274.

Mulder J., Christophersen N., Kopperud K., Fjeldal P.H., 1995. Water flow paths and the spatial distribution of soils as a key to understanding differences in streamwater chemistry between three catchments (Norway). Water, Air and Soil Pollution. 81(1-2): 67-91. DOI: 10.1007/BF00477257.

OGIMET, 2018. Global Summary Of the Day (GSOD): Kasprowy Wierch. Online: www.ogimet.com/cgi-bin/gsodres?lang=e n\&ind $=126500-99999 \&$ ord $=$ DIR \&ano $=2016 \&$ mes $=03 \&$ day $=31$ \&ndays $=31-01.12 .2018$.

Perrin J., Jeannin P. Y., Cornaton F., 2007. The role of tributary mixing in chemical variations at a karst spring, Milandre, Switzerland. Journal of Hydrology 332(1-2): 158-173. DOI:10.1016/j. jhydrol.2006.06.027.

Piotrowska K., Danel W., Iwanow A., Gaździcka E., Rączkowski W., Bezák V., Mgalay J., Polák M., Kohút M., Gross P., 2015. Mapa Geologiczna. W: K.Dąbrowska, M.Guzik (red.), Atlas Tatr - przyroda nieożywiona, Ark. IV.1 Budowa Geologiczna, Wydawnictwa Tatrzańskiego Parku Narodowego, Zakopane.
Poor C.J., McDonnell J.J., 2007. The effects of land use on stream nitrate dynamics. Journal of Hydrology 332(1-2): 54-68. DOI: 10.1016/j.jhydrol.2006.06.022.

Sandén P., Karlsson S., Düker A., Ledin A., Lundman L., 1997. Variations in hydrochemistry, trace metal concentration and transport during a rain storm event in a small catchment. Journal of Geochemical Exploration 58(2-3): 145-155. DOI: 10.1016/ S0375-6742(96)00078-7.

Siwek J., 2012. Zmienność składu chemicznego wód w małych zlewniach na progu Pogórza Karpackiego. Instytut Geografii i Gospodarki Przestrzennej UJ, Kraków: 1-112.

Siwek J., Siwek J.P., Żelazny M., 2013. Environmental and land use factors affecting phosphate hysteresis patterns of stream water during flood events (Carpathian Foothills, Poland). Hydrological Processes 27(25): 3674-3684. DOI: 10.1002/hyp.9484.

Siwek J.P., Żelazny M., Chełmicki W., 2013. Environmental and land use determinants of stream water chemistry during flood events in small Carpathian Foothill catchments in Poland. W: J.Kozak, K.Ostapowicz, A.Bytnerowicz, B.Wyżga (red.), The Carpathians: integrating nature and society towards sustainability. Environmental Science and Engineering, Springer-Verlag Berlin, Heidelberg: 161-178.

Siwek J.P., Żelazny M., Siwek J., Szymański W., 2017. Effect of land use, seasonality, and hydrometeorological conditions on the $\mathrm{K}^{+}$concentration-discharge relationship during different types of floods in Carpathian Foothills Catchments (Poland). Water, Air and Soil Pollution 228(11): 445. DOI: 10.1007/ s11270-017-3585-0.

Skiba S., Koreň M., Drewnik M., Kukla J., 2015. Gleby. W: K.Dąbrowska, M.Guzik (red.), Atlas Tatr - przyroda nieożywiona, Ark. VI.1 Gleby. Wydawnictwa Tatrzańskiego Parku Narodowego, Zakopane.

Smolska E., 1996. Funkcjonowanie systemu korytowego w obszarze młodoglacjalnym na przykładzie górnej Szeszupy (Pojezierze Suwalskie). Wydział Geografii i Studiów Regionalnych UW, Warszawa: 1-123.

Stottlemyer R., 2001. Processes regulating watershed chemical export during snowmelt, fraser experimental forest, Colorado. Journal of Hydrology 245(1-4): 177-195. DOI: 10.1016/S00221694(01)00352-3.

Walling D.E., Foster I.D.L., 1975. Variations in the natural chemical concentration of river water during flood flows, and the lag effect: some further comments. Journal of Hydrology 26(3-4): 237-244. DOI: 10.1016/0022-1694(75)90005-0.

Walling D.E., Webb B.W., 1980. The spatial dimension in the interpretation of stream solute behaviour. Journal of Hydrology 47(1-2): 129-149. DOI: 10.1016/0022-1694(80)90052-9.

Wit K., Ziemońska Z., 1960. Hydrografia Tatr Zachodnich: objaśnienia do mapy hydrograficznej Tatry Zachodnie 1:50 000. PAN Instytut Geografii, Kraków: 1-99.

Zwoliński Zb., 1989. Geomorficzne dostosowywanie się koryta Parsęty do aktualnego reżimu rzecznego. Dokumentacja Geograficzna 3/4: 1-144.

Żelazny M., 2012. Czasowo-przestrzenna zmienność cech fizykochemicznych wód Tatrzańskiego Parku Narodowego. Instytut Geografii i Gospodarki Przestrzennej UJ, Kraków: 1-285. 